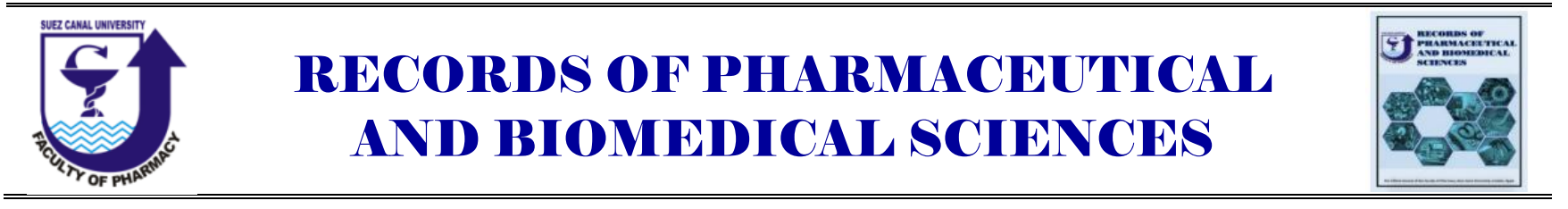

\title{
HPLC Determination of Metronidazole in Pure Form, Pharmaceutical Dosage form and Spiked Urine.
}

\author{
Khaled Karam $^{\text {a }}$, Randa A. Abdel Salam ${ }^{\text {b }}$ and Ghada M. Hadad ${ }^{b}$ \\ ${ }^{a}$ * Department of Pharmaceutical Analytical Chemistry, Faculty of Pharmacy, Al Azhar University, Assuit, \\ Egypt, ${ }^{b}$ Department of Pharmaceutical Analytical Chemistry, Faculty of Pharmacy, Suez Canal University, \\ Ismailia, Egypt.
}

\section{Received on: 1.11. 2018}

Revised on: 25. 11.2018

Accepted on: 29. 11. 2018

Correspondence Author:

Tel:+ 01005707242.

E-mail address:

khaled20385@yahoo.com

\begin{abstract}
A new HPLC method for the determination of Metronidazole was established. The determination was performed by using a Kinetex $\mathrm{C} 18$ analytical column with a gradient mobile phase system consisting of $0.05 \mathrm{M} \mathrm{KH}_{2} \mathrm{PO}_{4}(\mathrm{pH} 3.5), \mathrm{pH}$ adjusted with ortho phosphoric acid (mobile phase A) and Acetonitrile (mobile phase B). The flow rate was $1 \mathrm{ml} / \mathrm{min}$. and quantitation was achieved with UV detection at $230 \mathrm{~nm}$, based on peak area. The retention time obtained was 5.35 \pm 0.004 and the method was validated according to ICH guidelines regarding linearity, limit of detection (LOD), limit of quantification (LOQ), precision, accuracy, robustness, and selectivity. Excellent linearity was observed for the calibration curve with an excellent correlation coefficient 0.9999. Limit of detection was $0.78 \mu \mathrm{g} \mathrm{mL}-1$; limit of quantitation $2.37 \mu \mathrm{g} \mathrm{mL}-1$. The developed method was found to be accurate and sensitive and is ideally suited for analysis of MTZ in pure form, pharmaceutical dosage form and spiked urine samples.
\end{abstract}

Keywords: HPLC, Metronidazole, pharmaceutical dosage form, spiked urine.

\section{Introduction:}

Metronidazole (MTZ) is (2-Methyl-5-nitro-1Himidazol-1-yl) ethanol, a synthetic nitroimidazole derivative with antiprotozoal and antibacterial activities. It inhibits nucleic acid synthesis by disrupting the DNA of microbial cells (Metla 2015). This function only occurs when metronidazole is partially reduced, and because this reduction usually happens only in anaerobic cells, it has relatively little effect upon human cells or aerobic bacteria (Schaechter, Engleberg et al. 2012). Reduced metronidazole causes DNA strand breaks, thereby inhibiting DNA synthesis and bacterial cell growth. It is still the drug of choice for treatment of anaerobic infections and considered to be a cost-effective drug because of its low cost, good activity against pathogenic anaerobic bacteria, favorable pharmacokinetic and pharmacodynamic properties, and minor adverse effects (Löfmark, Edlund et al. 2010). Different analytical methods were proposed for analysis of MTZ in pure form, different pharmaceutical preparations and biological fluids, including, Spectrophotometric methods (Nagaraja, Sunitha et al. 2002, Saffaj, Charrouf et al. 2004, Saffaj, Charrouf et al. 2006), HPLC methods (Akay, Özkan et al. 2003, Tavakoli, Varshosaz et al. 2007, Suyagh, Iheagwaram et al. 2010), electrochemical methods (Lü, Wu et al. 2004, Bartlett, Ghoneim et al. 2005, Peng, Hou et al. 2012), capillary electrophoresis methods (Jin, Li et al. 2000) and HPTLC method 
(Meshram, Bagade et al. 2009). So the aim of this work is the determination of MTZ mainly in human urine and also in pharmaceutical dosage forms and pure form.

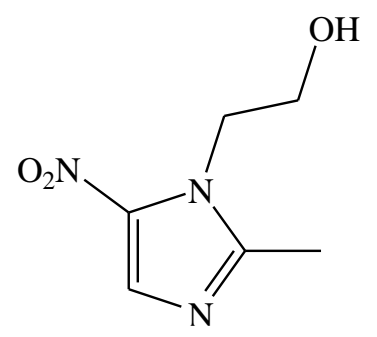

Figure 1: chemical structure of MTZ

\section{Experimental:}

\subsection{Materials \& reagents}

All reagents used during the study were of HPLC grade. MTZ was kindly provided by Egyptian int. pharmaceutical industry Co. (E.I.P.I.Co) $10^{\text {th }}$ of Ramadan city, industrial area B1, Egypt and certified to contain $99.6 \%$. Potassium dihydrogen phosphate and phosphoric acid were purchased from El Nasr chemical Co., (Abo Zaabal ,Cairo, Egypt). Water, methanol, and acetonitrile HPLC grade were purchased from Merk. All solutions used during the process were filtrated through Whatman polytetrafluoroethylene (PTFE) membrane filter $0.2 \mu \mathrm{m}$ that was purchased from Sigma Aldrich. All sample solutions were filtered through Whatman (PTFE) $0.2 \mu \mathrm{m}$ syringe filter, was purchased from Sigma Aldrich. 0.05M of $\mathrm{KH}_{2} \mathrm{PO}_{4}$ was prepared by dissolving the calculated amount from $\mathrm{KH}_{2} \mathrm{PO}_{4}$ in one liter HPLC water then the $\mathrm{pH}$ was adjusted to 3.5 with ortho phosphoric acid.

\subsection{Pharmaceutical dosage form}

Flagyl ${ }^{\circledR}$ tablets, were labeled to contain $500 \mathrm{mg}$ MTZ per tablet (Batch No. 7EG013), manufactured by Sanofi Egypt.

\subsection{Preparation of standard drug solutions 2.3.1 Stock solutions}

Stock standard solution $\left(100 \mu \mathrm{g} \mathrm{ml}^{-1}\right)$ was prepared by transferring accurately weighted 10 $\mathrm{mg}$ of MTZ into $100 \mathrm{ml}$ volumetric flask, diluted with about $70 \mathrm{ml}$ methanol and sonicated for 10 min then the flask was diluted to $100 \mathrm{ml}$ with methanol to obtain stock solution $\left(100 \mu \mathrm{g} \mathrm{ml}^{-1}\right)$, and stored in refrigerator at $4 \mathrm{C}^{\circ}$ Each prepared stock solution was further diluted immediately before use, to obtain a working solution within the concentration range.

\subsubsection{Urine samples}

Different volumes of MTZ stock standard solution were transferred to $10 \mathrm{ml}$ volumetric flasks, $1 \mathrm{ml}$ blank urine was added. Acetonitrile was used as protein precipitating agent to remove any proteinous material. The solutions were diluted to $10 \mathrm{ml}$ with mobile phase to obtain concentration range from 5 to $75 \mu \mathrm{g} \mathrm{ml}^{-1}$ of MTZ.

\subsection{Chromatographic conditions}

HPLC analysis was performed according to the following conditions;

The HPLC separation and quantitation were made on a 100 x 4.6 mm (i.d.) Kinetex C18 (2.6 $\mu$ m particle size) analytical column. The mobile phase was $0.05 \mathrm{M} \mathrm{KK_{2 }} \mathrm{PO}_{4}(\mathrm{pH} 3.5$ ) (mobile phase A) and Acetonitrile (mobile phase $\mathrm{B}$ ). The gradient program consisted of 0-5 min 80\% mobile phase A; 5-10 min gradient up to $50 \%$ mobile phase A. After 10 min the gradient was returned to the initial condition and the analytical column was reconditioned for $10 \mathrm{~min}$. The flow rate was $1 \mathrm{ml} \mathrm{min-1.} \mathrm{All} \mathrm{determinations} \mathrm{were}$ performed at $25^{\circ} \mathrm{C}$ temperature. The injection volume was $10 \mu \mathrm{l}$. The detector was set at $230 \mathrm{~nm}$. The calibration curves were obtained by plotting each drug concentration against the corresponding peak area.

\subsection{Procedure for pharmaceutical dosage forms}

Ten tablets of Flagyl ${ }^{\circledR} 500 \mathrm{mg}$ were finally powdered and mixed thoroughly. An accurate amount equivalent to $10 \mathrm{mg} \mathrm{MTZ}$ was weighted and transferred to a100 ml volumetric flask, dissolved in about $70 \mathrm{ml}$ of the mobile phase, the flask content was swirled well, sonicated for $10 \mathrm{~min}$, and completed to $100 \mathrm{ml}$ with mobile phase. The flask content was mixed well and filtrated through Whatman (PTFE) membrane filter $0.2 \mu \mathrm{m}$, the first portion of the filtrate was rejected. The obtained stock solutions were further diluted with the mobile phase to obtain final solutions within the concentration range of the calibration.

\section{Results and discussion}

The method aims to develop, simple, sensitive, rapid, HPLC method for determination of MTZ in pure \& pharmaceutical dosage forms and also spiked urine. 


\subsection{Chromatographic conditions}

The drug separation is obtained using mobile phase consists of $0.05 \mathrm{M} \mathrm{KH}_{2} \mathrm{PO}_{4}(\mathrm{pH} \mathrm{3.5)}$ ) and acetonitrile in the described ratio, a Kinetex 2.6 C18 column $100 \mathrm{~A}(4.6-\mathrm{mm} \times 10-\mathrm{mm})$ as stationary phase, and flow rate of $1 \mathrm{ml} / \mathrm{min}$. The separation of the studied drug at these conditions gives optimum retention time, peak area; the retention time was $5.35 \pm 0.004$.

\subsection{Optimization of variables}

Different experimental parameters affecting the separation and the peak area of the studied drug were studied and optimized. The studied factors were the composition of mobile phase, the buffer $\mathrm{pH}$, and buffer concentration each of this factors were changed individually while the others remain unchanged.

\subsection{Validation of the proposed analytical method}

The proposed analytical method was validated according to ICH guidelines (Guideline 2005) regarding linearity, limit of detection (LOD), limit of quantification (LOQ), precision, accuracy, robustness, and selectivity.

\subsubsection{Linearity and range}

The linearity of the proposed HPLC method was evaluated by analyzing a series of standard solution of MTZ with different concentrations ranges from $5 \mu \mathrm{g} \mathrm{ml}^{-1}$ to $75 \mu \mathrm{g} \mathrm{ml}{ }^{-1}$, under the optimum experimental conditions mentioned above, the calibration curve of the studied drug was obtained by plotting value the concentration of the drug against each corresponding peak area, each concentration was repeated three times. Statistical treatment of the data was carried out by using linear regression analysis and different analytical parameters were calculated Table 1 . The correlation coefficient (r) was 0.9999 which indicates excellent linearity.

\subsubsection{Limit of detection (LOD) and limit of quantitation (LOQ)}

According to International Conference on Harmonization (ICH) recommendations (ICH 2005), LOD and LOQ were determined. The LOQ and LOD were based on standard deviation of response, and slope of calibration curve using the equations; $\mathrm{LOD}=3.3 \sigma / \mathrm{S}$ and $\mathrm{LOQ}=10 \sigma / \mathrm{S}$, where. $\sigma$ is standard deviation of intercept, $\mathrm{S}$ is the slope of calibration curve, the obtained results were summarized in Table 3. The limit of detection was $0.78{\mu \mathrm{gml}^{-1}}^{-1}$ and limit of quantitation was 0.83 $\mu \mathrm{gml}^{-1}$. This indicates a high sensitivity of the proposed HPLC analytical method when compared with other reported analytical methods

Table 1: The analytical parameters of MTZ determination by the proposed HPLC analytical method

\begin{tabular}{cc}
\hline Parameter & MTZ \\
\hline & \\
\hline Concentration range $\left(\mu \mathrm{g} \mathrm{ml}^{-1}\right)$ & $5-75 \mu \mathrm{gml}^{-1}$ \\
& \\
Correlation coefficient $(\mathrm{r})$ & 0.9999 \\
Determination coefficient $\left(\mathrm{r}^{2}\right)$ & 0.9999 \\
Intercept & 0.852 \\
Slope & 5.631 \\
SD of the intercept $(\mathrm{Sa})$ & 1.336 \\
$\mathrm{SD}$ of slope $(\mathrm{Sb})$ & 0.030 \\
LOD $\left(\mu \mathrm{g} \mathrm{ml} l^{-1}\right)$ & 0.78 \\
LOQ $\left(\mu \mathrm{g} \mathrm{m} l^{-1}\right)$ & 2.37 \\
\hline
\end{tabular}

LOD: limit of detection, $L O Q$ : limit of quantitation

\subsubsection{Accuracy and precision}

The accuracy of the proposed analytical method was evaluated at five concentrations level within the specific range of the studied drug. Each concentration was replicated three times. The mean of the three measurements was calculated as found. The results of the three measurements were represented as percent of recovery \pm standard deviation, (table 2). The obtained results were in close agreement with the true values, which indicates a high accuracy of the proposed method.

In order to evaluate the precision of the proposed analytical method, both intra-day precision and interday precision were evaluated. The intra-day precision was evaluated by replicate analysis of three concentrations of the studied drug on three successive times. The inter-day precision was also evaluated by replicate analysis of 3 concentrations 
over a period of three successive days. Both results of intra-day and inter-day precision were summarized in Table 3 . The calculated relative standard deviation of different measurements was below $2 \%$ which indicates the excellent precision of the proposed HPLC analytical method at both levels of repeatability and intermediate precision.

Table 2: Evaluation of the accuracy of the proposed HPLC analytical method for the determination of MTZ

\begin{tabular}{cccc}
\hline Sample number & $\begin{array}{c}\text { Taken } \\
\left(\mu \mathrm{g} \mathrm{m}^{-1}\right)\end{array}$ & $\begin{array}{c}\text { Found }^{\mathrm{a}} \\
\left.(\mu \mathrm{gg} \mathrm{m})^{-1}\right)\end{array}$ & \% recovery \\
\hline 1 & 5 & 4.98 & 99.6 \\
2 & 10 & 10.08 & 100.8 \\
3 & 20 & 20.09 & 100.45 \\
4 & 30 & 29.85 & 99.5 \\
5 & 50 & 49.56 & 99.12 \\
Mean & & & 99.89 \\
SD & & & 0.70 \\
RSD & & & 0.70 \\
\%RE & & & 0.11 \\
\hline
\end{tabular}

SD: standard deviation, RSD: relative standard deviation. ${ }^{a}$ Mean of three replicate measurements

\subsubsection{Selectivity}

High selectivity of the method was approved by preparing MTZ in blank urine in concentrations within the linearity range. The laboratory prepared mixture was analyzed according to the previous procedure described under the proposed HPLC method. Satisfactory results were obtained in Table 4, indicating the high selectivity of the proposed methods for determination of MTZ in the presence of urine matrix.

\subsubsection{Robustness}

To examine the robustness of the proposed HPLC method one experimental variable was changed individually while the other variables remain constant. The studied variables were $\mathrm{pH}$ of buffer solution, the composition of the mobile phase and concentration of buffer solution. To test the effect of buffer $\mathrm{pH}$, the $\mathrm{pH}$ varies from 3.3 to 3.7 , to test
Table 3: Evaluation of the intraday and interday precision of the proposed HPLC analytical method for determination of MTZ

\begin{tabular}{cccc}
\hline $\begin{array}{c}\text { Precision } \\
\text { level }\end{array}$ & $\begin{array}{c}\text { Conc. } \\
\left(\mu \mathrm{m} \mathrm{m}^{-1}\right)\end{array}$ & $\%$ Recovery ${ }^{\mathrm{a}} \pm \mathrm{SD}$ & $\mathrm{RSD}$ \\
\hline Intraday & 5 & $100.03 \pm 1.09$ & 1.09 \\
& 10 & $99.43 \pm 0.90$ & 0.90 \\
& 20 & $99.75 \pm 0.75$ & 0.75 \\
& 5 & $100.1 \pm 1.25$ & 1.25 \\
Interday & 10 & $99.63 \pm 0.75$ & 0.75 \\
& 20 & $99.09 \pm 1.41$ & 1.41 \\
\hline
\end{tabular}

SD: standard deviation, RSD: relative standard deviation. ${ }^{a}$ Mean of three replicate measurements.

Table 4: Determination of MTZ in spiked urine using the proposed HPLC method

\begin{tabular}{ccc}
\hline Sample No. & $\begin{array}{c}\text { Added conc. } \\
\left(\boldsymbol{\mu g m l ^ { - 1 } )}\right.\end{array}$ & \% Recovery $^{\mathbf{e}}$ \\
\hline 1 & 10 & 99.71 \\
2 & 20 & 99.87 \\
3 & 60 & 100.03 \\
4 & 50 & 100.92 \\
5 & 25 & 99.61 \\
Mean & & 100.03 \\
SD & & 0.52 \\
\hline
\end{tabular}

SD: standard deviation. ${ }^{a}$ Mean of three replicate measurement

the effect of buffer concentration, the concentration varies from $48 \mathrm{mM} \mathrm{KH_{2 }} \mathrm{PO} 4$ to $52 \mathrm{mM} \mathrm{KH} 2 \mathrm{PO} 4$ and to test the effect of mobile phase composition the percent of mobile phase composition varies from

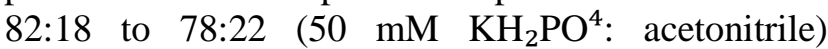
respectively. The obtained results were summarized in Table 5 indicating that small variations in any of these variables did not significantly affect the results of the suggested method. 
Table 5: Robustness study of the proposed HPLC method for determination of MTZ (40 $\left.\boldsymbol{\mu g m l}^{-1}\right)$.

\begin{tabular}{cc}
\hline Variation & $\%$ Recovery \pm SD \\
\hline Optimum condition & \\
Effect of pH (phosphate buffer) & \\
$\mathrm{pH} 3.7$ & $100.69 \pm 0.84$ \\
$\mathrm{pH} 3.3$ & $100.25 \pm 1.27$ \\
Effect of Buffer concentration & \\
$52 \mathrm{mM}$ & $99.27 \pm 0.90$ \\
$48 \mathrm{mM}$ & $98.88 \pm 1.25$ \\
Effect of mobile phase composition & \\
(gradient elution) & \\
(82:18) & \\
(50mM phosphate buffer: acetonitrile) & $99.63 \pm 1.19$ \\
(78:22) & $99.95 \pm 1.01$ \\
\hline
\end{tabular}

SD: standard deviation. ${ }^{a}$ Mean of three replicates measurements.

\subsubsection{Analytical solutions stability}

In anticipation of unexpected delays during analysis it is important to have information about the stability of all solutions. When the stability of MTZ in the mobile phase was tested, it was found that samples were stable for at least for 12 hours when kept at room temperature, protected from light, and for 2 days when stored refrigerated at $5^{\circ} \mathrm{C}$ as it exhibited no chromatographic or absorbance

changes. The stability of spiked Urine during storage for 2 weeks at $-20^{\circ} \mathrm{C}$ was also evaluated; no significant change was observed.

\subsection{Application to pharmaceutical dosage form}

The proposed method was successively applied for the determination of the studied drug in its pharmaceutical dosage form (Flagyl ${ }^{\circledR}$ tablet). The interference of the tablet excipients was observed in order to determine the selectivity of the proposed HPLC method. The results obtained were summarized in Table 6. From the table, it was shown that there is no significant difference
Table 6: Comparison between the proposed HPLC analytical method and reported methods for determination of MTZ in its pharmaceutical dosage form

\begin{tabular}{|c|c|c|c|c|}
\hline \multirow[t]{2}{*}{ Dosage form } & \multicolumn{2}{|c|}{$\%$ Recovery ${ }^{2} \pm$ SD } & \multirow{2}{*}{ t-value b } & \multirow{2}{*}{ F-value } \\
\hline & Proposed & Reported ${ }^{\circ}$ & & \\
\hline $\begin{array}{c}\text { Flagyl@ tablet } \\
500 \mathrm{mg} \mathrm{MTZ/} \mathrm{tablet}\end{array}$ & $99.78 \pm 0.78$ & $\begin{array}{c}99.91 \pm 1.09 \\
\text { (Nagaraja,Sunitha } \\
\text { et al. 2002) }\end{array}$ & 0.39 & 1.47 \\
\hline
\end{tabular}

${ }^{a}$ The values are mean of five determinations. The tabulated $t$ - and $F$-values at $95 \%$ confidence limit are 2.78 and 6.39 , respectively. ${ }^{c}$ Reported method.

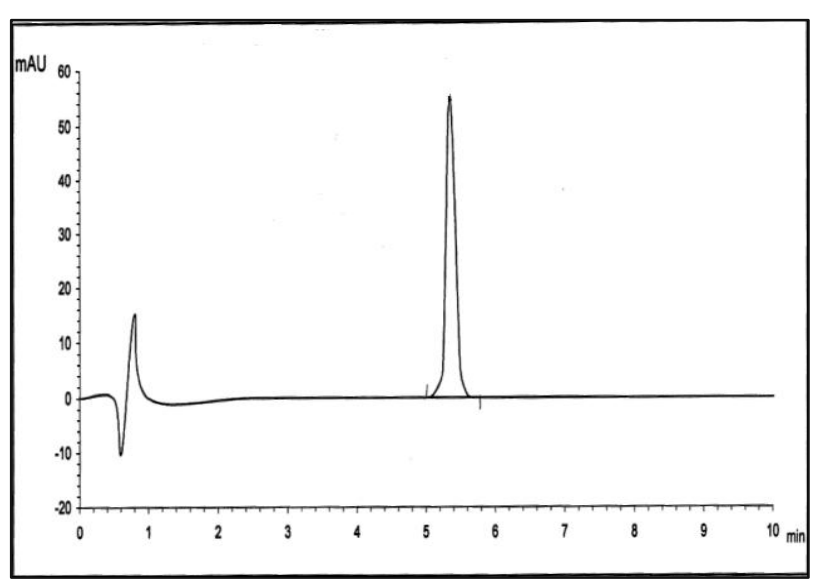

Figure 2: Chromatogram of spiked urine with MTZ $\left(10 \mu \mathrm{g} \mathrm{ml}^{-1}\right)$.

between results obtained from the proposed method and from reported method as indicated by student's ttest and F-test, as the calculated value did not exceed the theoretical value at $95 \%$ confidence level. This indicates a high accuracy of the proposed method.

\section{Conclusion:}

This work provides a new analytical method for the determination of MTZ in pure form, pharmaceutical dosage form and spiked urine.

The method has the advantages of being rapid, sensitive, selective and relatively low cost so can be used for routine analysis in quality control. 


\section{5- References:}

Akay, C., et al. (2003). "Simultaneous determination of metronidazole and miconazole in pharmaceutical dosage forms by RP-HPLC." Il Farmaco 57(11): 953-957.

Bartlett, P., et al. (2005). "Voltammetry and determination of metronidazole at a carbon fiber microdisk electrode." Talanta 66(4): 869-874.

Guideline, I. H. T. (2005). Validation of analytical procedures: text and methodology Q2 (R1). International Conference on Harmonization, Geneva, Switzerland.

ICH, I. (2005). Q2 (R1): Validation of analytical procedures: text and methodology. International Conference on Harmonization, Geneva.

Jin, W., et al. (2000). "Quantitative assay of metronidazole by capillary zone electrophoresis with amperometric detection at a gold microelectrode." ELECTROPHORESIS: An International Journal 21(7): 1409-1414.

Löfmark, S., et al. (2010). "Metronidazole Is Still the Drug of Choice for Treatment of Anaerobic Infections." Clinical infectious diseases 50(Supplement_1):S16-S23.

Lü, S., et al. (2004). "Electrochemical reduction and voltammetric determination of metronidazole at a nanomaterial thin film coated glassy carbon electrode." Talanta 63(3): 653-657.

Meshram, D. B., et al. (2009). "Simultaneous determination of metronidazole and miconazole nitrate in gel by HPTLC." Pakistan journal of pharmaceutical sciences 22(3).

Metla, S. (2015). Evaluation of drug release \& anti-bacterial activity of metronidazole from dermatological bases using reduced level of the drug, Long Island University, The Brooklyn Center.

Nagaraja, P., et al. (2002). "Spectrophotometric determination of metronidazole and tinidazole in pharmaceutical preparations." Journal of pharmaceutical and biomedical analysis 28(3-4): 527-535.

Peng, J., et al. (2012). "Determination of metronidazole in pharmaceutical dosage forms based on reduction at graphene and ionic liquid composite film modified electrode." Sensors and Actuators B: Chemical 169: 81-87.

Saffaj, T., et al. (2004). "Spectrophotometric determination of metronidazole and secnidazole in pharmaceutical preparations." Il Farmaco 59(10): 843-846.

Saffaj, T., et al. (2006). "Spectrophotometric determination of Metronidazole and Secnidazole in pharmaceutical preparations based on the formation of dyes." Dyes and pigments 70(3): 259-262.

Suyagh, M. F., et al. (2010). "Development and validation of a dried blood spot-HPLC assay for the determination of metronidazole in neonatal whole blood samples." Analytical and bioanalytical chemistry 397(2): 687-693.

Schaechter, M., et al. (2012). Schaechter's mechanisms of microbial disease, Lippincott Williams \& Wilkins.

Tavakoli, N., et al. (2007). "Development and validation of a simple HPLC method for simultaneous in vitro determination of amoxicillin and metronidazole at single wavelength." Journal of pharmaceutical and biomedical analysis 43(1): 325329. 